\title{
Ethnicity and child mortality in sub-Saharan Africa
}

\section{Martin Brockerhoff}

Population Council

Paul C. Hewett

Population Council

Follow this and additional works at: https://knowledgecommons.popcouncil.org/departments_sbsr-pgy

Part of the Demography, Population, and Ecology Commons, Education Commons, Family, Life Course, and Society Commons, International Public Health Commons, and the Maternal and Child Health

Commons

How does access to this work benefit you? Let us know!

\section{Recommended Citation}

Brockerhoff, Martin and Paul C. Hewett. 1998. "Ethnicity and child mortality in sub-Saharan Africa," Policy Research Division Working Paper no. 107. New York: Population Council. 


\section{Ethnicity and Child Mortality in sub-Saharan Africa}

M artin B rockerhoff Paul H ewett 


\title{
Ethnicity and Child Mortality in sub-Saharan Africa
}

\author{
Martin Brockerhoff \\ Paul Hewett
}

Martin Brockerhoff is Associate and Paul Hewett is Research Staff Associate, Policy Research Division, Population Council.

Support for this research from NICHD Grant 1-RO1-HD33718-01 is gratefully acknowledged. 


\begin{abstract}
Analysis of recent survey data reveals large differentials in child mortality among ethnic groups in countries throughout sub-Saharan Africa. These disparities correspond with the prominence of specific ethnic groups in the national political economy. In many countries where heads of state since independence have come from one or two ethnic groups-as in Côte d'Ivoire, Kenya, and Niger-these groups have experienced levels of early child mortality at least one-third lower than those of other groups. In other countries where there have been several transitions in state control, as in Ghana and Uganda, descendants of precolonial kingdoms such as Ashanti and Buganda have experienced much lower mortality than others. In most countries, the lower mortality of potent ethnic groups-who typically represent small proportions of national populations-is strongly related to economic privilege. Persistent inequalities among African ethnic groups deserve strong consideration in planning economic development and child health strategies.
\end{abstract}

This material may not be reproduced without written permission from the authors. 
Journalistic accounts of wars in Rwanda, Somalia, and several other countries of sub-Saharan Africa in the 1990s have raised concerns that ethnic cleavages and overlapping affiliations of religion and race may undermine prospects for economic and political development in much of Africa (Kaplan 1994). ${ }^{1}$ The threat of elevated child mortality from internecine violence has been cited, in particular, based on the young age structure of African populations, the dependency of children on adults, and the invariably high proportion of child combatants in recent disputes (UNICEF 1996).

Paradoxically, there has been no systematic examination of ethnic inequality in child survival chances across countries in the region, including the majority of African countries that have experienced relative peace over the past decade or more. Nor has there been significant advancement of a theoretical model by which one might test the political, economic, and cultural mechanisms through which ethnic affiliation affects child mortality across highly diverse African settings. These shortcomings are conspicuous insofar as early cross-national analysis of ethnicity and mortality, using data from the 1960s and 1970s, concluded that "ethnicity...exerts a strong influence on mortality in countries where ethnic groups appear to be sharply differentiated" (Mensch, Lentzner, and Preston 1985:86). Neglect of mother's ethnicity, in particular, as an influence on child survival is remarkable in light of the countless studies that have emphasized the central importance of maternal characteristics and behavior for child health in Africa.

This paper uses survey data from 12 countries to examine whether ethnic inequality in child mortality is indeed pervasive throughout sub-Saharan Africa. ${ }^{2}$ The focus is on child mortality since the early 1980s. To understand how ethnicity affects child mortality, we introduce below a conceptual framework and test its central hypotheses. While some African offspring are the product of interethnic marriages, the analysis centers on the ethnic 
affiliation of the mother, given women's typically heavy responsibility, whether imposed or appropriated, for childrearing. ${ }^{3}$ Of special interest to this study is the relationship between child survival and the dominance of certain ethnic groups in the national political economy. Specifically, given that national political authority in many stable African countries has been assumed by one or two minority ethnic groups for most of the independence era, while other more volatile countries have been guided indirectly by groups with historical economic advantages, we investigate whether such dominance has conferred child survival advantages to members of these groups, and if so, how.

\section{CONCEPTUAL ISSUES}

The few comparative studies of ethnic group mortality in Africa are mostly based on births and deaths in the 1960s and 1970s. These demographic studies generally reveal enormous differentials but provide scant interpretation of these discrepancies. Tabutin and Akoto (1992), for instance, found that the probability of dying before age two was twice as high among the Luo as among the Kikuyu in Kenya, and 40 percent higher among the Hutu than among the Tutsi in Rwanda. In Cameroon, ethnic membership was the strongest predictor of child survival chances. While these findings went unexplained, the authors concluded that "the ethnic variable should always be controlled in a study of mortality" (p. 54). A more intensive analysis of Cameroon data showed that Hauossa-Foulbe children had higher neonatal mortality than others-presumably because of a high incidence of venereal disease among their parents - but lower mortality thereafter, perhaps because of some combination of dietary factors and reduced exposure to

acute diseases (Kuate Defo 1992). Two separate studies uncovered that the Peul (or Fulani), one of the largest ethnic groups in the Sahel region, had 10 
percent higher mortality under age two than the majority Bambara in central Mali (Hill and Randall 1984), but 30 percent lower mortality than the majority Wolof and Serer in the Sine-Saloum region of Senegal (Cantrelle and Livenais 1980). Both studies speculated that group differences in child care, notably in nutritional practice, accounted for variation in mortality. The Tonga of the Gwembe District in southern Zambia had 20 percent higher child mortality $\left({ }_{5} q_{0}\right)$ than the country's population as a whole in the mid-1960s (234 as compared to 190 deaths per 1000 live births), but experienced a onethird decline by the early 1990s (to 156/1000) while the national level remained stable (Clark et al. 1995). Differential mortality decline was attributed, in this case, to an exhaustive set of expanded preventive health care services in Gwembe. ${ }^{4}$

Such imprecise accounting for ethnic child mortality differences no doubt reflects the heterogeneity of social and ecological settings in Africa. As Hill (1985:63) observed from surveys in Mali, "the very different life styles of the different ethnic groups comprising the national population of any Sahelian country are likely to have characteristic patterns of mortality and fertility even though the physical environment may be roughly comparable between the groups." We maintain, however, that insufficient explanation of clear-cut ethnic mortality disparities points as well to the absence of a general model of ethnicity and child mortality to guide analysis and support explanation. This shortcoming is unfortunate, for as Gaisie (1990:613) asserts with respect to African cultures, "ethnic frameworks are necessarily the most important determinants of the degree of adaptation to modern conditions including changes in health behavior."

Figure 1 proposes that ethnic affiliation affects child survival through its influence on a household's economic conditions, the cultural status of 
Figure 1 Conceptual framework of ethnicity and child survival in subSaharan Africa

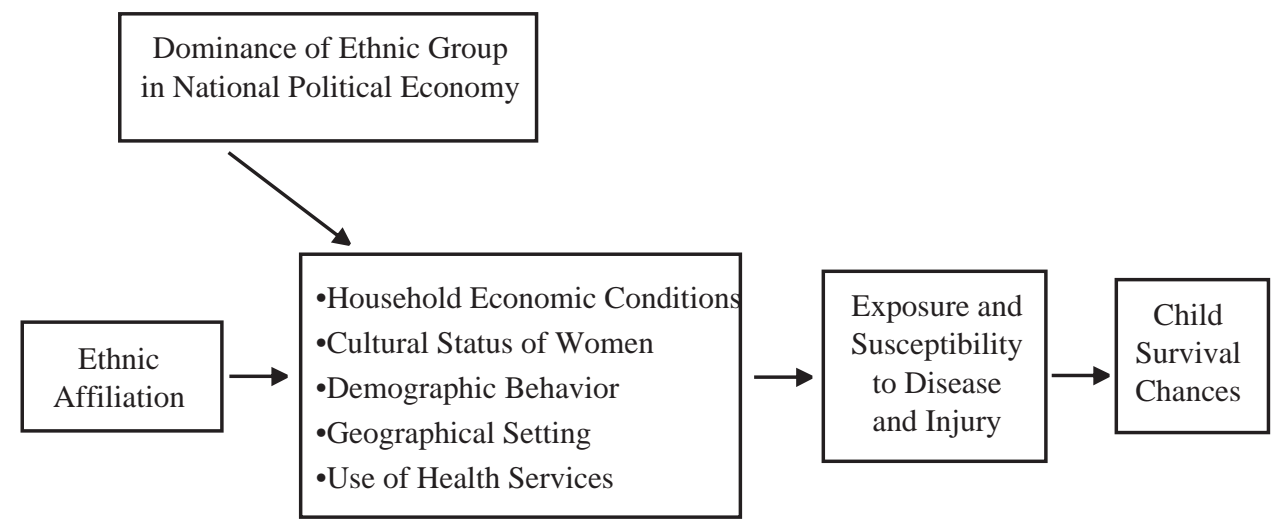

mothers, demographic (i.e., reproductive and migratory) behavior, an individual's geographical setting, and the extent to which modern health care services are used. In most African settings, these features generally distinguish members of different ethnic groups. Kenya provides a useful illustration. Whereas Somali groups in Northeastern Province and the Luhya of Western Province are highly mobile (Gould 1988)—hence exposed to multiple disease environments and potentially to new infectious disease agents99 percent of Kalenjin-speaking people remain sedentary in Rift Valley Province (Kitching 1980), where the epidemiological setting is less conducive to the spread of measles and malaria (Brass and Jolly 1993; Ewbank, Henin, and Kekovole 1986; Mosley 1983). Kenya's fertility rate has dropped considerably in recent years (National Council for Population and Development 1994), but Gusii women in the southwest are still expected to bear a child every two years until menopause and have much higher completed fertility than the national average (LeVine et al. 1994). The Kikuyu clustered in 
Nairobi and surrounding Kikuyuland, meanwhile, were the beneficiaries of economic and education entitlements bestowed by British colonialists (Harden 1990), but traditionally they also place higher cultural value on female education than do the Luo (Krieger 1993). And although it is presumed that in more-advanced developing countries such as Kenya all households will rely on modern preventive child health care given effective motivation and convenient access to it, a study in the Machakos district uncovered that some ethnic groups, such as the Akamba, will frequently apply traditional practices to remove "bewitching" spirits that afflict ill children before resorting to modern medicine (van Ginneken 1990).

Most critically, in many African countries child survival is affected indirectly as well by the prominence of ethnic groups in the national political economy. We hypothesize that child survival chances are typically enhanced for members of a potent group, mainly as a result of favorable economic conditions in their households and communities. Comparative economic advantages may result, for instance, by means of an uneven distribution of state-controlled resources and publicly conferred entitlements, including health services, in favor of areas where a particular ethnic group is located or directly to members of that group. Such channeling of economic benefits may represent a persistence of discriminatory practices dating to the colonial era-one that enabled ethnic groups in some countries to secure dominance in national governance at the time of independence and to maintain it — or may be a product of contemporary African politics.

The mortality of ethnic groups in Africa cannot be understood without consideration of the national political and economic context. The creation and manipulation of ethnic, racial, and religious inequality in the African 
colonial state — wherein one indigenous group was typically favored over all others-was countered effectively by some African leaders in the immediate postcolonial years of nation-building, either through explicit corrective policies or by ideological pronouncements that suppressed factionalism. Nonetheless, however sincere Nyerere, Senghor, and other early leaders were in their exhortations toward pan-Africanism, the independence era of many countries of sub-Saharan African has clearly been marked by a relative dominance of one or two ethnic groups in the control of state functions (Jackson and Rosberg 1982; Londregan, Bienen, and van de Walle 1995). These groups, as categorized by Morrison, Mitchell, and Paden (1989), are described in Table 1 for the 12 countries included in this study.

National supremacy of specific ethnic groups in African states takes at least three distinct forms. It has been most blatant in the many countries where heads of state have come exclusively from one ethnic group, and occasionally two. This characterizes long periods of firm one-man rule by Kaunda in Zambia, Kenyatta and Moi in Kenya, Houphouët-Boigny in Côte d'Ivoire, Bokassa and Kolingba in the Central African Republic (C.A.R.), and elsewhere (for instance, Mugabe in Zimbabwe), as well as countries in which state leadership has been passed between members of the same group (as among the Djerma-Songhai in Niger). With few exceptions, such as the C.A.R., these countries have been politically stable. Since most leaders of these countries have come from "minority" groups that represent small proportions of the national population, or from a fractured majority group with a long history of interethnic rivalry — as among the Shona ethno-linguistic group of Zimbabwe-national political rule inevitably has necessitated the co-opting of other ethnic groups, clans, or kinship affiliates in order to extend government authority throughout the country. Such practice was per- 
Table 1 Dominant ethnic groups in 12 countries of sub-Saharan Africa

\begin{tabular}{|c|c|c|c|}
\hline Country & Ethnic Group & $\begin{array}{l}\text { Percent of } \\
\text { National } \\
\text { Population }\end{array}$ & $\begin{array}{c}\text { Head of State } \\
\text { from } \\
\text { Ethnic Group }\end{array}$ \\
\hline \multirow{2}{*}{$\begin{array}{l}\text { Central African } \\
\text { Republic }\end{array}$} & M'baka & 7 & 1966-79 (Bokassa) \\
\hline & Yakoma & 8 & 1980-93 (Kolingba) \\
\hline Côte d'Ivoire & Baoulé & 20 & $\begin{array}{l}\text { 1960-present } \\
\text { (Houphouët-Boigny; Bédié) }\end{array}$ \\
\hline \multirow[t]{2}{*}{ Ghana } & Ashanti & 28 & 1969-79 (Several) \\
\hline & & & 1982-present (Rawlings) ${ }^{1}$ \\
\hline \multirow[t]{2}{*}{ Kenya } & Kikuyu & 21 & 1963-78 (Kenyatta) \\
\hline & Kalenjin & 11 & 1978-present (Moi) \\
\hline Mali & Bambara & 31 & 1968-91 (Traoré) \\
\hline Namibia & Ovambo & 46 & $\begin{array}{l}\text { 1990-present } \\
\text { (Nujoma) }{ }^{1}\end{array}$ \\
\hline Niger & Djerma-Songhai & 24 & $\begin{array}{l}\text { 1960-93 } \\
\text { (Diori; Kountche; } \\
\text { Saibou) }\end{array}$ \\
\hline \multirow[t]{5}{*}{ Nigeria } & \multirow{5}{*}{$\begin{array}{l}\text { Hausa, } \\
\text { Fulani, Tiv, } \\
\text { and Plateau } \\
\text { Cluster }\end{array}$} & \multirow[t]{5}{*}{45} & 1960-66 (Balewa) \\
\hline & & & 1966-75 (Gowon) \\
\hline & & & 1975-76 (Mohammed) \\
\hline & & & 1979-85 (Shagari) \\
\hline & & & 1985-93 (Babangida) \\
\hline Rwanda & Hutu & 90 & $\begin{array}{l}\text { 1962-94 } \\
\text { (Kayibanda; } \\
\text { Habyarimana) }\end{array}$ \\
\hline Senegal & Serer & 19 & $\begin{array}{l}\text { 1960-present } \\
\text { (Senghor; Diouf) }\end{array}$ \\
\hline Uganda & Baganda & 16 & 1979 (Lule; Binaisa) \\
\hline Zambia & Bemba & 15 & 1964-91 (Kaunda) \\
\hline
\end{tabular}

Notes: ${ }^{1}$ Rawlings is non-Ashanti; his wife is a member of the Ashanti royal family. ${ }^{2}$ The Ovambo led the SWAPO independence movement prior to 1990.

Sources: Morrison, Mitchell, and Paden 1989; for Nigeria, Metz 1992. 
petuated most effectively, perhaps, by Mobutu in Zaire, himself a member of a group (the Ngwandi) that comprises less than one percent of the national population (Callaghy 1984). A small ethnic power base, however, does not necessarily diminish government practice of ethnic favoritism. For example, while Kikuyu participation is indispensable to the maintenance of Moi's regime in Kenya, the ruling party, KANU, is perceived to have become a vehicle to promote Kalenjin political sentiments (Conteh-Morgan 1997).

In other countries, especially those where there have been several transitions in heads of state, the national dominance of particular ethnic groups cannot be traced to recent political rule, but derives instead from these groups' favorable economic position since the colonial period or earlier. The Baganda of southern Uganda, still concentrated around Lake Victoria on the fertile soil of the ancient Buganda Kingdom, have exercised their economically favorable setting and an ethnocentrism (that is, a sense of ethnic superiority) based on a legacy of autonomous nationhood before British imperialism to exert strong indirect influence over governments led by autocrats from smaller groups, including Obote and Amin (Kasfir 1976; Mazrui 1978). Indeed, President Museveni, though a member of the Banyankole, has symbolically revived the Kabaka, or king of Buganda, to garner this group's support. In Ghana, despite their pronounced abhorrence of "tribalism," non-Ashanti national leaders from Nkrumah to Rawlings have inevitably depended on local Ashanti leaders from Ghana's resourceful interior-often presumed descendants of the Ashanti kingdom - to cement their authority and to generate economic growth. Rawlings's wife is in fact a member of the Ashanti royal family (Campbell 1997:72). In Namibia, the SWAPO party that led the two-decade fight for independence in 1990 was comprised mainly of educated, disenfranchised Ovambo members from the north (Griffiths 1993). 
A third, less common, and more ambiguous form of ethnic dominance has occurred where specific groups or coalitions have maintained control of elected or military governments despite historical or geographical circumstances that place them at economic disadvantage in relation to other ethnic groups in their countries. These dominant groups may have experienced less favorable living conditions and survival chances in recent years than comparable ethnic groups in other African countries where political or economic dominance has been more obvious or has occurred in combination. In Rwanda, for instance, the First Republic of 1959-90 was composed entirely of Hutu cabinet members. Yet, German and Belgian colonialists had applied theories of racial superiority to create a Tutsi aristocracy from the 1890s to 1959 , one whose economic advantages persisted until the civil war of 1994 (Newbury 1988; Prunier 1995). And Nigeria's many governments since 1960 have reflected a superficial inclusion of all three major ethnic groups at various periods, but the Hausa, Fulani, and northern plateau minorities such as the Tiv and Gwari, when not represented by elected heads of state, have maintained effective control of a "militocracy" since the 1960s (Umoren 1995). Most members of these groups, however, are located in remote areas of northern Nigeria, at considerable remove from the resources concentrated in Lagos and surrounding Yorubaland, and far from the oil-producing southeastern region of Igboland.

\section{DATA AND METHODS}

Our data come from 12 countries of sub-Saharan Africa that conducted Demographic and Health Surveys (DHS) between 1990 and 1995. These represent 11 surveys of this period in which ethnic affiliation was asked directly of women of reproductive age, as well as the Nigeria DHS, where 
ethnicity can be deduced from detailed responses to a question on local language of the respondent. ${ }^{5}$ Nine of these surveys were nationally representative: For reasons of security, the Kenya DHS did not encompass the Eastern and Northeastern Provinces, which comprise less than 4 percent of the national population. The Mali survey omitted rural areas of Gao and Timbouctou, representing 10 percent of the population, while the Uganda DHS did not survey the Acholi population in the northernmost Kitgum district, who account for less than 5 percent of Uganda's population. The Rwanda survey was conducted immediately pre-crisis, in 1992, while for the other countries, except Namibia, the period studied here-roughly the early 1980s to mid-1990s — was one of relative nonviolence on a national scale.

The variables used in the regression analyses of mortality are described in Appendix A. ${ }^{6}$ All variables represent individual- and household-level characteristics and have well-documented relationships with child mortality in African settings. Ethnic group membership is categorized simply as a dichotomous or trichotomous measure in order to test whether nationally prominent groups have enjoyed better survival chances, but also because dozens of ethnic groups are identified in some surveys. ${ }^{7}$ For six countries where the head of state since independence has come from one or two ethnic groups, rural community-level variables are available to describe (1) the modernity of infrastructure, as measured by the community's access to a paved or allweather road, and (2) the community's proximity to a public health facility. Our premise is that members of these ethnic groups enjoy more favorable conditions - for instance, shorter distance to a health facility - even outside urban areas as result of nonrandom placement of resources or uneven economic development patterns among ethnic communities, or as a result of the superior means of some groups and areas to meet their demand for goods 
and services (for instance, by having more money). We depart from the conventional grouping of variables as "indirect" and "proximate" determinants of mortality, and conceptualize them instead (as in Figure 1) as indicators of household economic conditions, the cultural status of women, demographic behavior, geographical setting, and use of modern preventive health care services for children - factors that broadly distinguish ethnic groups in many African countries.

The analysis proceeds as follows. After descriptive comparisons, bivariate logit regression is used to assess whether the groups most empowered in the national political economy in each country experienced lower odds of child mortality than did other ethnic groups (that is, the majority of residents in most of these countries) in the ten years preceding the surveys. Comparable data on ethnic affiliation from the World Fertility Survey (WFS) are used along with DHS data to also examine 20-year trends in early child mortality $\left({ }_{2} q_{0}\right)$ among ethnic groups in Côte d'Ivoire, Kenya, and Senegal.

Second, multivariate logit procedures are applied to determine whether infant mortality differentials among ethnic group members are more closely related to household economic conditions, as hypothesized, than to differences in women's status, demographic behavior, geographical settings, or preventive health care practices. Multivariate analysis is based on births in the five years preceding the surveys, since health service information is not available for earlier births. We examine mortality during infancy, rather than at other ages, since infant mortality is the most universally accepted measure of comparative wellbeing across countries and subnational populations (Sen 1993). The multivariate models can be summarized simply as:

$$
\operatorname{Ln}(\mathrm{P} / 1-\mathrm{P})=\alpha+\beta_{\mathrm{Ehi}}+\beta_{\mathrm{Zhi}}
$$


where the dependent variable represents the log-odds of dying before age 12 months for the ${ }_{i}$ th child of household ${ }_{h} \alpha$ denotes the constant term, $\beta_{E}$ represents a dummy variable for ethnic affiliation and its associated coefficients, and $\beta_{\mathrm{Z}}$ denotes all other covariates (that is, sets of economic, demographic, and other factors) and their associated coefficients. The child's household, ${ }_{h}$, is identified to adjust for potential intrahousehold correlation of mortality risks. The five sets of covariates denoted by ${ }_{Z}$ (see Appendix A) are introduced in five separate models, with each model also considering the effects of ethnic affiliation. ${ }^{8}$ Of interest is whether any observed survival advantage or handicap of ethnic group members is modified upon consideration of each individual set of factors, and if so, by how much. A benchmark model, where mortality probabilities depend on ethnic affiliation only, is used for these comparisons. We interpret a substantial decline in group members' advantage, for instance after controlling for national variance in economic status variables, to mean that their lower mortality has resulted in part from economic privilege. A variation of the Hausman (1978) test is used to assess the statistical significance of any change in the log-odds of mortality of an ethnic group upon consideration of economic conditions, the status of women, and other sets of factors. ${ }^{9}$ This test can be expressed simply as the difference in the ethnicity coefficients between the benchmark and other models, divided by the difference in the variance of the ethnicity coefficients, or

$$
\frac{\hat{\beta}_{2}-\hat{\beta}_{1}}{\sqrt{s e^{2} \hat{\beta}_{2}-s e^{2} \hat{\beta}_{1}}} .
$$

To summarize the effects of economic status and other factors on ethnic infant mortality differentials in each country, parameter estimates are 
exponentiated, and percentage changes in ethnic mortality differentials resulting from each set of characteristics are calculated based on the relative change in the odds ratios of the ethnicity variable between models. The relevant formula is:

$$
\left(\frac{\text { EthnicOddsRatioModel2 }}{\text { EthnicOddsRatioModel1 }}\right)-1
$$

For example, assume first that the Ashanti of Ghana have odds of infant mortality of 0.66 when only ethnic affiliation is considered in Model I (or 34 percent lower than the 1.00 odds of other Ghanaians). Then, after controlling for national variance in economic status variables in Model II, the odds of infant mortality among the Ashanti become 0.83 . Therefore, differences in economic status between the Ashanti and other Ghanaians improve the survival chances of Ashanti infants by 25.8 percent ((.83/.66)-1). A result of 7 percent after controlling for national variance in the status of women would suggest that economic inequality plays a greater role in contributing to child survival inequality between ethnic groups in Ghana.

\section{DESCRIPTIVE RESULTS}

Table 2 presents selected characteristics of ethnic groups in the 12 countries, pertaining to the status of women, economic conditions, use of health care, and geographical setting. These variables also typically affect child survival chances in low-income countries. The statistics reveal that members of prominent ethnic groups in sub-Saharan Africa are generally advantaged as compared to the majority of the population in their countries, who belong to other groups. One partial exception is in Kenya, where 
Kalenjin-speakers were relatively disadvantaged in 1993 even after 15 years of rule by President Moi. As expected, longtime national government rule by the Hausa, Fulani, and northern plateau ethnic minorities in Nigeria, and by the Hutu in Rwanda as of 1992, had not resulted in advantages for households and women of these groups.

Levels of female education vary enormously across African countries, with about 10 percent of women having attended school in Niger as compared to over 80 percent in Kenya, Namibia, and Zambia. In most countries, however, there are large disparities in schooling between ethnic groups, either in absolute or relative terms. In the C.A.R., roughly 70 percent of Yakoma and M'baka women attended school, as compared to 45 percent of other women. Among women in Ghana and Uganda, 84 percent of Ashanti and 95 percent of Baganda received some education, as compared to about 60 percent of others. In Niger, women who belong to the culturally affiliated Djerma and Songhai-despite both being patrilineal societies—are twice as likely to have attended school as are other Nigeriennes.

Men's occupations and the availability of electricity in dwellings are obvious indicators of households' economic status and modernity. In most countries, dominant ethnic groups have been advantaged according to at least one, and usually both, of these characteristics. In Côte d'Ivoire, 36 percent of Baoulé men and 27 percent of others have occupations that presumably draw higher pay than agriculture, fishing, services, or unskilled labor. Even in Namibia, Ovambo men are more likely to hold modern-sector jobs than are other non-Europeans in the country, despite their typical location far from Windhoek. And while relatively few dwellings in East Africa, for instance, have electricity, those of the Kikuyu in Kenya, the Baganda in Uganda, and 
Table 2 Characteristics of ethnic groups in 12 countries (in percent) ${ }^{\mathrm{a}}$

\begin{tabular}{|c|c|c|c|c|c|}
\hline $\begin{array}{l}\text { Country and } \\
\text { Survey Year } \\
\end{array}$ & $\begin{array}{l}\text { Women } \\
\text { Attended } \\
\text { School } \\
\end{array}$ & $\begin{array}{c}\text { Modern } \\
\text { Occupation } \\
\text { of } \\
\text { Husbands }^{\mathbf{b}} \\
\end{array}$ & $\begin{array}{c}\text { Electricity } \\
\text { in } \\
\text { Dwellings }\end{array}$ & $\begin{array}{c}\text { Children } \\
\text { Received } \\
\text { Complete } \\
\text { Immunization } \\
\end{array}$ & $\begin{array}{c}\text { Living in } \\
\text { Largest City }^{\mathrm{d}} \\
\end{array}$ \\
\hline \multicolumn{6}{|c|}{ Central African Republic, 1994/95 } \\
\hline Yakoma & $71.3 * *$ & $27.3^{*}$ & $8.5^{*}$ & $63.3^{* *}$ & $40.9^{* *}$ \\
\hline M'baka & $67.9^{* *}$ & $35.5^{* *}$ & $13.6^{* *}$ & 37.7 & $40.0^{* *}$ \\
\hline All Other & 44.5 & 21.9 & 4.3 & 36.4 & 17.7 \\
\hline \multicolumn{6}{|l|}{ Côte d'Ivoire, 1994} \\
\hline Baoulé & $49.5^{* *}$ & $36.3^{* *}$ & $54.2 * *$ & $46.3^{* *}$ & 15.1 \\
\hline All Other & 39.0 & 27.2 & 41.6 & 34.8 & 15.7 \\
\hline \multicolumn{6}{|l|}{ Ghana, 1993} \\
\hline Ashanti & $84.1 * *$ & $32.1 *$ & $43.1 * *$ & $60.8^{* *}$ & 19.8 \\
\hline All Other & 60.4 & 27.2 & 30.6 & 49.7 & 18.6 \\
\hline \multicolumn{6}{|l|}{ Kenya, 1993} \\
\hline Kikuyu & $90.5^{* *}$ & $36.3 *$ & $18.4 * *$ & $89.2^{* *}$ & $10.8^{* *}$ \\
\hline Kalenjin & 80.1 & $21.9^{* *}$ & $5.3^{* *}$ & 72.9 & $0.6 * *$ \\
\hline All Other & 80.7 & 33.0 & 11.4 & 70.7 & 11.6 \\
\hline \multicolumn{6}{|l|}{ Mali, 1995/96 } \\
\hline Bambara & $20.6^{*}$ & $9.9^{*}$ & $8.5^{*}$ & $37.8^{*}$ & 13.3 \\
\hline All Other & 18.0 & 11.6 & 9.7 & 31.3 & 12.9 \\
\hline \multicolumn{6}{|l|}{ Namibia, 1992} \\
\hline Ovambo & $88.2 * *$ & $37.4 *$ & $11.5^{* *}$ & $60.3^{* *}$ & $7.5^{*}$ \\
\hline European & $97.2 * *$ & $61.2 * *$ & $77.2 * *$ & $61.4^{* *}$ & $42.8^{* *}$ \\
\hline All Other & 78.4 & 30.3 & 23.8 & 46.9 & 9.9 \\
\hline \multicolumn{6}{|l|}{ Niger, 1992} \\
\hline Djerma-Songhai & $16.8^{* *}$ & 9.2 & $7.7 * *$ & $22.8^{* *}$ & $36.5^{* *}$ \\
\hline All Other & 8.9 & 8.6 & 4.4 & 13.9 & 15.4 \\
\hline \multicolumn{6}{|l|}{ Nigeria, 1990} \\
\hline Hausa/Plateau Cluster & $8.8 * *$ & $5.0^{* *}$ & $15.6^{* *}$ & $14.0^{* * *}$ & $0.1^{* *}$ \\
\hline All Other & 52.9 & 22.5 & 47.6 & 39.3 & 20.0 \\
\hline \multicolumn{6}{|l|}{ Rwanda, 1992} \\
\hline Hutu & $60.3^{*}$ & $9.9 *$ & $2.4^{* *}$ & $78.3^{*}$ & $9.3^{* * *}$ \\
\hline Tutsi & $80.2 * *$ & 15.3 & 8.3 & 84.9 & 25.0 \\
\hline \multicolumn{6}{|l|}{ Senegal, 1992/93 } \\
\hline Serer & 25.3 & 32.4 & $19.7 * *$ & $63.4^{* *}$ & $19.7 * *$ \\
\hline All Other & 26.9 & 34.8 & 31.0 & 49.0 & 24.6 \\
\hline \multicolumn{6}{|l|}{ Uganda, 1995} \\
\hline Baganda & $95.1^{* *}$ & $41.4^{* *}$ & $26.8^{* *}$ & $62.5^{* *}$ & $23.1 * *$ \\
\hline All Other & 64.3 & 21.0 & 5.5 & 49.3 & 3.9 \\
\hline \multicolumn{6}{|l|}{ Zambia, 1992} \\
\hline Bemba & $89.0 * *$ & $38.6^{* *}$ & $28.4 * *$ & 65.4 & $9.2^{* *}$ \\
\hline All Other & 81.0 & 31.6 & 22.3 & 64.5 & 16.0 \\
\hline
\end{tabular}

$* \mathrm{p} \leq .05, * * \mathrm{p} \leq .01$

a'Statistics are derived from surveys of women ages 15-49. All missing values and "Don't Know" responses deleted. $\quad$ 'Professional, technical, managerial, clerical, or skilled manual. 'Based on children ages 12-59 months. Received BCG, measles, DPT 1-3, and Polio 1-3 immunization. in countries where urban areas were over- or underrepresented in sample design. 
Bemba-speakers in Zambia are much more likely than others' to possess this valuable resource.

Most striking has been the highly disparate use of immunization services between ethnic groups in virtually all countries, despite the formal commitment of all governments to universal primary health care. In the Sahelian states of Mali, Niger, and Senegal, for instance, complete immunization coverage is significantly higher among groups that have had highlevel government representation than among other groups. As the so-called child survival revolution of governments and international health organizations proceeded since the late 1970s, Yakoma children in the C.A.R. apparently benefited much more so than did others in the country. In Kenya, the Kalenjin's completely rural concentration has not translated into lower use of immunization than among other non-Kikuyu, who are much more urbanized.

There is no consistent evidence that the aforementioned ethnic inequalities are related to groups' relative concentration in the largest cities of these countries, which are known to contain a disproportionate share of each country's material resources as compared to the spatial distribution of national populations (Gugler 1996). Advantages of the Djerma-Songhai, Tutsi, and Baganda in their countries, and of European descendants in Namibia, may be attributable to these groups' large presence in the biggest cities. However, the Baoulé, Ashanti, Kikuyu, Ovambo, and Bemba experience several advantages despite similar or smaller concentrations of population in the largest cities as compared to other groups.

Table 3 presents rural community data available from surveys in six of these countries. Data in Table 3, while limited, show a consistent bias in road infrastructure and access to public health services in favor of ethnic groups that have held political power. While road access is poor throughout rural C.A.R., 
Table 3 Rural community characteristics of ethnic group members in six countries

Median Distance to

Percent with

All-Weather Road
Public Health

Facility ( $k$ m.)

Central African Republic, 1994/95

Yakoma

M'baka

Other
Baoulé

Other

Kenya, 1993

Kikuyu

Kalenjin

Other

Mali, 1995/96

Bambara

Other

Niger, 1992

Djerma-Songhai

Other

Senegal, 1992/93

Serer

Other
$65.9^{* *}$

47.8
$3.3^{*}$

$12.9 * *$

1.3

$41.6^{* *}$

31.3

$4.1 *$

$3.3^{* *}$

4.5

$3.9^{*}$

4.5

$14.6 * *$

$17.9^{*}$

19.8

$9.9 * *$

$49.2 * *$

5.9

62.5

$16.8^{*}$

$22.1 *$ a

9.9

$13.0^{\mathrm{a}}$

$* \mathrm{p} \leq .05, * * \mathrm{p} \leq .01$

aPercent living within 50 kilometers of a public health facility

Mali, and Niger, where the majority of the population lives, the M'baka, Bambara, and Djerma-Songhai are much more likely than others to live in rural communities that are served by all-weather surfaces. Côte d'Ivoire and Senegal have served as regional transportation nodes for French colonialists and investors, and therefore are more thoroughly developed in the countryside, but members of the Baoulé 
and Serer nevertheless have much more favorable road access than others. A similar pattern of ethnic differentials appears with respect to access to public health facilities in these countries, as well as in Kenya. In rural Senegal, for instance, the median distance for Serer women to a health facility is a substantial 34 kilometers, but this is half as remote as for women from other ethnic groups.

The following section examines whether these marked differentials between ethnic groups correspond to differential levels and trends in child mortality.

\section{CHILd SURVIVAL INEQUALITY AMONG ETHNiC GROUPS: BIVARIATE RESULTS}

Table 4 presents odds ratios of mortality at ages $0-11,0-23$, and $0-59$ months, by ethnic group. A ratio of 0.78 , for instance, represents a 22 percent lower chance of dying for a child of a given ethnic group as compared to children of other groups in that country; 1.37 denotes a 37 percent higher chance.

Results show remarkable consistency. In all 12 countries there are significant differentials between ethnic groups in the odds of dying for at least one age group. In most countries, strong disparities appear in each age group; in a few countries, such as Rwanda and the Sahelian states of Mali and Senegal, they exist only among children under age one or two years. In the two countries examined where there has been frequent turmoil since independence and where the prominence of an ethnic group derives most purely from gross economic advantages, Ghana and Uganda, large inequalities in child survival chances exist as well. In Ghana, children of Ashanti women are about 20 percent less likely to die than are other Ghanaian children. In Uganda, Baganda children have experienced more than one-third lower odds of dying before age five than children of other ethnic groups. 
Table 4 Odds ratios of child mortality by ethnic group, 1980-95

Country, survey year

Central African Republic, 1994/95

All Other

Yakoma

M'baka

Côte d'Ivoire, 1994

All Other

Baoulé

Ghana, 1993

All Other

Ashanti

Kenya, 1993

All Other

Kalenjin

Kikuyu

Mali, 1995/96

All Other

Bambara

Namibia, 1992

All Other

Ovambo

European

Niger, 1992

All Other

Djerma-Songhai

Nigeria, 1990

All Other

Hausa/Plateau Cluster

Rwanda, 1992

Tutsi

Hutu

Senegal, 1992/93

All Other

Serer

Uganda, 1995

All Other

Baganda

Zambia, 1992

All Other

Bemba
Ages 0 to 11

months

1.000

0.890

$0.742 * *$

1.000

$0.735 * *$

1.000

$0.794^{*}$

1.000

$0.566^{* *}$

$0.355^{* *}$

1.000

$1.104 *$

1.000

$0.805^{*}$

0.756

1.000

$0.784 * *$

1.000

$1.293 * * *$

1.000

$1.374 * *$

1.000

$0.766^{* *}$

1.000

$0.723 * *$

1.000

$1.229 * *$
Ages 0 to 23

months

1.000

0.892

$0.788 *$

1.000

$0.738 * *$

1.000

0.780 **

1.000

$0.551 * *$

$0.327 * *$

1.000

1.079

1.000

$0.660 * *$

$0.837 *$

1.000

$0.667 * *$

1.000

$1.449 * * *$

1.000

$1.729 * * *$

1.000

1.000

$1.290 * *$

1.178

1.000

$0.789 * *$

1.000

1.049

1.000

$0.635^{* *}$

$0.717 * *$

1.000

1.000

$1.187 * *$

$* \mathrm{p} \leq .10, * * \mathrm{p} \leq .05, * * * \mathrm{p} \leq .01$

Note: Based on births in the ten years preceding the surveys. 
Large child mortality differences are evident in six of the eight countries where longtime politically dominant ethnic groups have also been economically advantaged. Children of the Baoule in Côte d'Ivoire and the Djerma-Songhai in Niger-groups that constitute less than one-quarter of their national populations - have about a 35 percent lower chance of dying before age five than other children in their countries. In Namibia, Ovambo children have an advantage of similar magnitude before age two. Inequities in Namibia are also evident by race, as European children had 37 percent lower odds of death before age five. Survival differences are particularly striking in Kenya. Kalenjin children have been half as likely to die before age five as other non-Kikuyu children, despite their almost exclusively rural residence. Meanwhile, odds of under-five mortality for the highly urbanized and politically active Kikuyu have been 65 percent lower among infants, and 74 percent lower among children under age five. Zambia is the notable exception to this pattern of association between child survival and ethnic prominence in the national political economy (differences in Mali are insubstantial). In Zambia - which experienced a sharp rise in child mortality in the 1980s (Gaisie, Cross, and Nsemikila 1993)—-the Bemba, traditionally occupied as migrant laborers in the northeast copperbelt region, witnessed slightly higher odds of child mortality, perhaps as a result of the collapse of the national copper market in the 1980s and widespread perinatal HIV transmission among migrant workers.

Finally, in the two countries, Nigeria and Rwanda, where politically dominant ethnic groups have been economically handicapped (as shown in Table 2), these groups have experienced child survival disadvantages as well. In Nigeria, children of the Hausa, Fulani, Tiv, and northern plateau groups 
have had greatly elevated child mortality odds as compared to other children in the country. The increasing disadvantage of these children with agefrom 29 percent higher mortality during infancy to 73 percent higher mortality among children under age five-points to an accumulation of disease assaults and nutritional deficiencies over time resulting from the harsh epidemiological environment of Hausaland and other parts of northern Nigeria. In Rwanda in the pre-crisis period of 1983-92, Hutu children under ages one and two had roughly one-third higher mortality odds than Tutsi children. This difference corresponds with a broad range of social and economic inequalities between the two ethnic groups in these years, as shown in Table 2.

The availability of comparable WFS data on ethnicity allows one to examine ethnic child mortality trends over a 20-year span (roughly 197090) in Côte d'Ivoire, Kenya, and Senegal. ${ }^{10}$ Figure 2 shows that in Côte d'Ivoire, the Baoulé have maintained consistently lower child mortality $\left({ }_{2} q_{0}\right)$ than other groups over time, even though they are not over-represented in Abidjan, where child mortality rates are lowest (Sombo et al. 1995). In Kenya, the Kikuyu experienced a 69 percent decline in mortality among birth cohorts that encompassed the 1970s, during most of which time President Kenyatta held office. By the 1980s child mortality levels among the Kikuyu were on par with those of many industrialized countries of the North (UNICEF 1997). At the same time, early-age mortality declined more slowly among the Kalenjin than among other non-Kikuyu groups (by 27 and 44 percent, respectively), but the Kalenjin subsequently enjoyed a decline of 37 percent between cohorts 1978-82 and 1983-87, coinciding with Moi’s consolidation of power (Ungar 1986). While strong cultural homogeneity may prevail in Senegal, the Serer, the ethnic group of Presidents Senghor and Diouf, 
Figure 2 Trends of mortality under age two $\left({ }_{2} q_{0}\right)$ by ethnic group (deaths per 1000 live births)
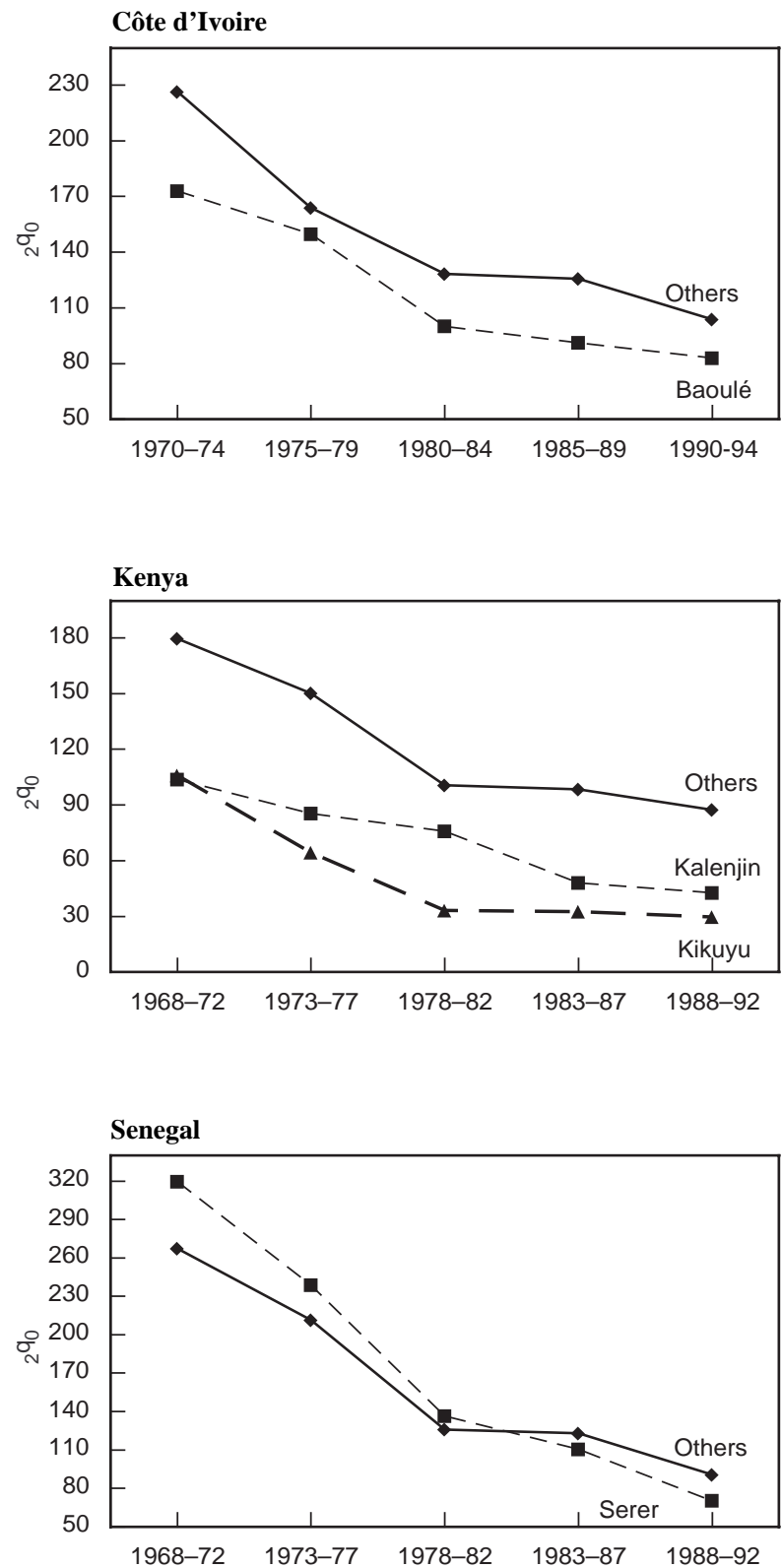
nonetheless underwent a more rapid decline in under-two mortality between cohorts 1968-72 and 1988-92 than did other groups (by 78 and 66 percent, respectively); a 20 percent survival disadvantage around 1970 was reversed to a 20 percent advantage by around 1990. The rapid and sustained decline in Serer child mortality-perhaps unparalleled in Africa - is particularly remarkable in that Serer women are disproportionately concentrated in rural areas of Senegal (Pison et al. 1995:111).

\section{Multivariate Results}

Table 5 shows the effects of ethnic affiliation and other characteristics on recent odds of infant mortality in each country. To facilitate the presentation of vast information, one ethnic group (or coalition in Nigeria) is examined in each country. The "benchmark" odds ratios of infant mortality shown in Model I are based on children born in the five years preceding the surveys - rather than on the ten-year birth cohorts examined in Table 4-hence they differ from the statistics for infants shown in Table 4. Yet, the direction and magnitude of ethnic mortality differentials are virtually identical in all countries in the two tables, suggesting that ethnic inequality in mortality levels has been entrenched throughout the 1980s and 1990s. The following discussion of Table 5 reviews the effects of variables other than ethnic affiliation on infant mortality across the 12 countries. ${ }^{11}$

Findings presented in Table 5 suggest that the child survival advantages of many potent ethnic groups in sub-Saharan Africa, on balance, may derive considerably from favorable economic situations. Indeed, the two indicators of household economic status estimated in Model II have pronounced effects on child survival. The presence of electricity in the dwelling reduces 


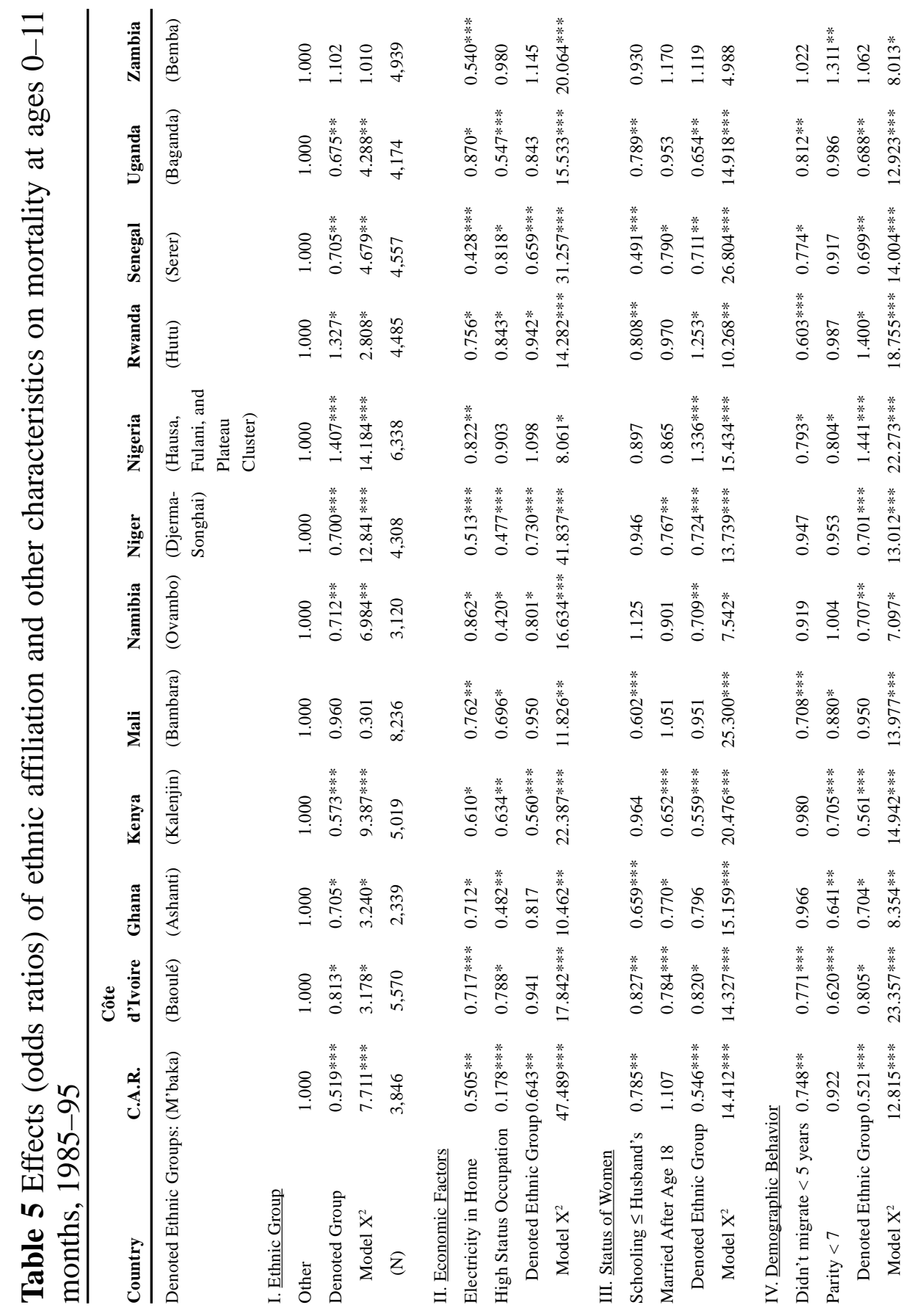




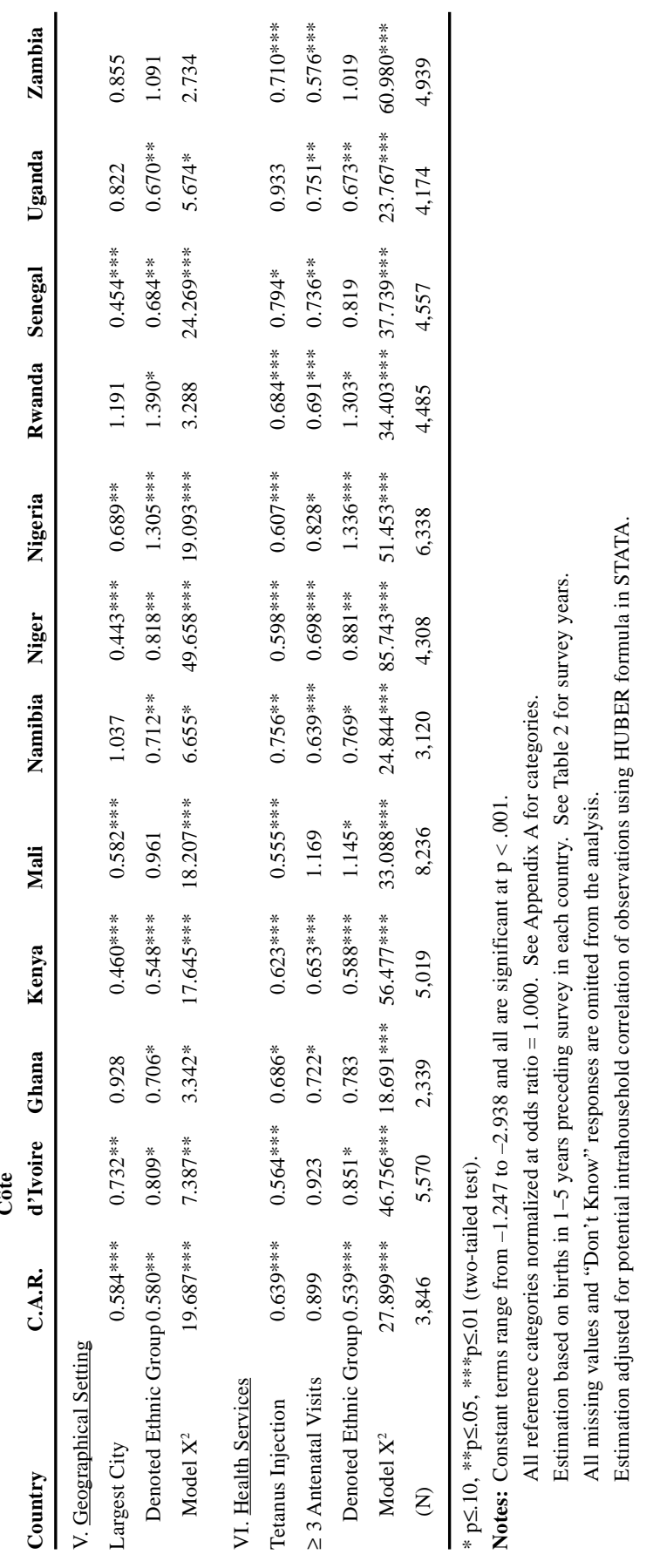


odds of death significantly in all 12 countries, ranging from 13 percent in Uganda to 50 percent in the C.A.R. In ten of the 12 countries odds are cut significantly when the husband or partner of the child's mother (that is, the working-age paternal figure in the household) has a modern occupation, which presumably results in more dispensable income for the household. In four of these countries, a high status occupation reduces the odds of infant mortality by more than half.

Measures of the cultural status of women, estimated in Model III, exhibit strong effects on infant survival in several countries, though not as widely as those of economic status. In seven of the 12 countries, infant survival chances are improved significantly in households where the mother's educational attainment is equal to or greater than that of her spouse. This impact of maternal schooling - which may reflect, among other things, an enhanced negotiation position and decisionmaking authority in the household with respect to child health issues-is most apparent in the predominantly Muslim countries of Mali and Senegal in the Sahel region, where it reduces mortality chances by 40 and 51 percent, respectively.

Model IV shows that recent migration has a deleterious effect on infant survival chances in seven countries-and nowhere improves survival chances - as odds are reduced by roughly 20 to 40 percent in these countries when the mother has not moved in the past five years (during which time the child was born). Heightened odds of infant mortality from migration may occur from the disruptive effects of a move (for instance, premature termination of breastfeeding, temporary isolation from health facilities and additional childrearers, or additional physical taxation during pregnancy or early postpartum), or from maladjustment to new surroundings after migration 
(for instance, an inability to speak the local dialect or to quickly obtain housing, health services, and income-earning opportunities). Being born as less than a seventh child, indicative in these high-fertility countries as potentially low comparative fertility for ethnic group members, reduces infant mortality in five countries.

Model $\mathrm{V}$ reveals that residing in the largest city of a country also significantly reduces infant mortality chances in seven of the 12 countries, although by substantial amounts in some countries (for instance, by more than half in Kenya, Niger, and Senegal). Of the two health services variables estimated in Model VI-having received at least one tetanus injection and three or more antenatal visits-at least one variable reduces the odds of infant mortality significantly in each country. The strong effects of preventive health care services on infant survival are expected, but it is surprising that in eight countries both of these variables lower mortality odds by 17 percent or more. This finding suggests that extensive modern prenatal care conveys benefits for early survival beyond those conferred by immunization against tetanus-the leading killer of African neonates.

Table 6 presents the percentage change in ethnic infant mortality differentials that results when one considers variation in the characteristics of different ethnic group members in each country. The bottom row of the table shows the odds ratio of infant mortality of prominent ethnic groups upon controlling for the full range of independent variables presented in the models (see Appendix A).

Variation in economic status is the strongest explanation for survival inequality in seven of the 12 countries. Infant survival among ethnic groups of interest in the C.A.R., Côte d'Ivoire, Ghana, Namibia, and Uganda has 


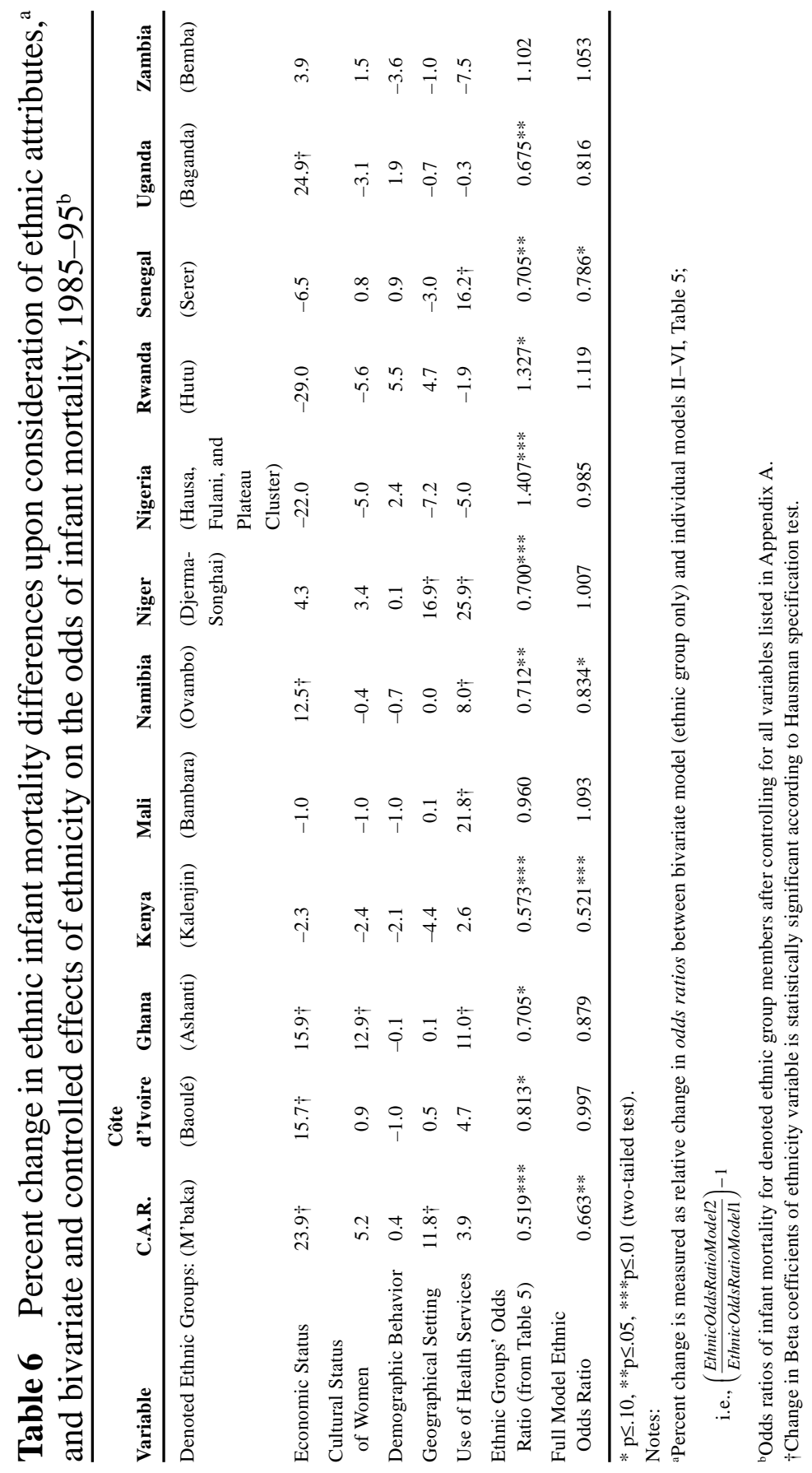


been improved (as compared to other groups) by 12 to 25 percent by the superior housing (measured by electricity) and men's occupations of these groups. ${ }^{12}$ Conversely, economic disadvantages worsened infant survival chances by 22 percent among politically dominant groups in Nigeria, and by 29 percent among the Hutu in Rwanda prior to 1992. In three countries- the Sahelian states of Mali, Niger, and Senegal-superior use or effects of child health services have been the dominant factors accounting for ethnic mortality differentials, in this case explaining much of the advantage of DjermaSonghai and Serer children, and in helping Bambara children to maintain infant mortality odds on par with other children in Mali (that is, infant mortality odds among the Bambara would have been 22 percent higher, relative to other groups, in the absence of variation in use of child health services between the Bambara and others). Bemba-speakers in Zambia may have experienced 10 percent higher infant mortality odds than other Zambians, but this would have been due almost entirely to lesser use or inferior effects of child health services among the Bemba. Whereas variation in fertility and migratory behavior has little bearing on ethnic mortality differentials in any country, the strong concentration of M'baka in Bangui, and of DjermaSonghai in Niamey (shown in Table 2), has contributed to better infant survival chances by more than 10 percent for these groups as compared to others in their countries. High modern status of women strongly benefits only children of the Ashanti in Ghana. The extreme survival advantage of Kalenjin children in Kenya is not explained by any of the variables considered in this analysis, although as noted earlier, the favorable disease environment of Rift Valley Province, where the group is almost exclusively located, likely plays a strong role in enhancing survival chances. 
The bottom row of Table 6 reveals that membership in a potent ethnic group retains a strong positive effect on child survival, independent of all other factors considered in the analysis, in four countries- the C.A.R., Kenya, Namibia, and Senegal. In the absence of additional explanatory information from the DHS, one can only speculate about the reasons for these residual effects. However, this result, combined with findings presented earlier, supports the inclusion of ethnic affiliation as a determinant of child survival in future African mortality research.

\section{DISCUSSION}

Based on analysis of survey data from the 1990s, this study has revealed large disparities in early child survival chances among ethnic groups in a wide range of African countries. These differentials are evident when one compares the recent mortality situations of ethnic groups that have been most powerful in the national political economy with those of other groups in these countries. Members of nationally prominent ethnic groups typically have much lower child mortality than the majority of the population in their countries-persons belonging to other ethnic groups-except in countries, such as Nigeria and prewar Rwanda, where monopolization of government leadership since independence has been assumed by groups that have historically been economically disadvantaged.

Descriptive statistics from households and rural communities suggest a close correspondence of mortality differentials with ethnic inequalities in household economic status, women's education, use of and access to health services, and community infrastructure. Multivariate analysis shows that ethnic mortality differences are, in fact, closely linked with economic inequal- 
ity in many countries, and with differential use of child health services in countries of the Sahel region, but seem to have little relationship with intergroup variation in geographical settings, demographic behavior, and the cultural status of women. One might therefore modify the broad analytical framework applied in this study to a simple pathway, one that links ethnic affiliation to child survival mainly through the national prominence of ethnic groups and resulting economic advantages at the household level, and still explain much of the difference in child mortality levels among ethnic groups at the national level in many countries.

A tempting conclusion is that in many countries dominant eliteswhether in national office, in control of the military, or comprising the bulk of the modern business class - may have channeled scarce state resources to areas where members of their ethnic groups are concentrated. Such ethnocentric practice may be an emerging dynamic of economic and political development in some African countries, whereas it may represent intractable historical ethnic cleavages elsewhere: proclaimed descendants of precolonial empires and states — for instance, Ashanti, Buganda, and Songhai — may have simply retained a historical superiority in living conditions as compared to neighboring populations contained within these countries. The strongest evidence of possibly deliberate uneven resource distribution is higher levels of complete child immunization - typically a free and universally desired service-in several countries among ethnic groups that have been represented at the highest levels of government, irrespective of these groups' concentration in the largest cities. An alternative, more benign explanation for ethnic inequality is that the benefits conferred upon the Baoulé, Kikuyu, and other ethnic groups by colonialists-discrimination that led some groups to se- 
cure political power around 1960-may have persisted over the past few decades, despite subsequent efforts of governments to promote more balanced economic and social development among the population. Neither of these hypotheses can be validated with existing data. In any case, however, the typical advantage of relatively small, clearly defined ethnic groups, as compared to the majority of national populations, according to fundamental indicators of wellbeing — child survival, education, housing, and so forthsuggests that many countries of sub-Saharan Africa, despite their widespread poverty, are as marked by social inequality as are countries in other world regions.

Our study is preliminary, insofar as it highlights only national inequalities, examines select groups, and offers superficial explanations of findings based on the limited data at our disposal. Nonetheless, strong and consistent results here strongly support placing the notion of ethnicity at the forefront of theories and analyses of child mortality in Africa that incorporate social, and not purely epidemiological, considerations. This emphasis might lead to better-informed child health policies. We find, for instance, that in Nigerwhere child mortality $\left({ }_{5} \mathrm{q}_{0}\right)$ levels are the highest in the world- mortality rates under age five around 1990 were about 242 among the Djerma but an astounding 353 for other Nigerienne children. In Kenya, which has one of the five lowest child mortality rates in tropical Africa, the non-Kikuyu experience child mortality levels that exceed the average of many African countries. ${ }^{13}$ Such intranational disparity questions the validity of targets solely for national mortality reduction, and of uniform methods to achieve such reduction, as established at the 1990 World Summit for Children. Clearly, a focus on some ethnic groups, and on the subnational areas where these groups 
are concentrated, is important for child survival efforts in African countries, and these groups and locales are likely to require unique strategies for optimal success of these efforts. Our findings suggest, however, that in the absence of policies to reduce economic disparities between groups, targeted child health interventions are likely to have limited impact on survival inequalities or disadvantages in many countries.

Beyond health policy, our findings argue for equal attention to politics in child health research on developing countries. The increasing instability of the political landscape, often along ethnic boundaries, of several areas of sub-Saharan African in the 1990s, concurrent in some countries with ominous demographic trends-growing involuntary or refugee migration, sluggish child mortality decline and rising adult mortality, persistent high fertility-supports greater consideration of political issues in African health research in particular. Health studies on Africa, however, have placed longstanding emphasis on population policy as a means of effecting desired changes in mortality and its determinants, while routinely neglecting the broader political context that often constrains successful implementation of health policies and programs. For instance, the ambition and earnestness of failed national health and population policies in Ghana in 1969 and in Nigeria in 1986 seem naive in light of the political instability that characterized these countries in preceding and following years. Similarly, the convention in demographic and child health research of deriving and summarizing policy prescriptions for countries, as in most of Africa, with seemingly intractable economic problems, nonrepresentative electoral processes or authoritarian governments, and generally fragile national institutions, carries little practical value for the most important stakeholders in the policy process- the large 
majority of the population who do not hold government office or dictate policy. Hence, recognition of the social groups that control government and decisionmaking seems imperative to more fully understand development concerns - in this case child mortality inequalities - in regions of sub-Saharan Africa, and to appreciate the feasibility of modifying undesirable patterns.

Appendix A Description of the variables used in the multivariate analysis

Variable

Dependent Variable:

Infant Mortality

Independent Variables:

I. Ethnic Group

II. Economic Status

Electricity in Dwelling

High Status Occupation of Husband/Partner

III. Cultural Status of Women

Educational Level $\geq$ Husband's

Married after Age 18

IV. Demographic Behavior

Migrated in Last 5 Years

Child is Parity 7 or Higher

V. Geographical Setting

Largest City

1. $\mathrm{No}^{*}$

2. Yes

1. $\mathrm{No}^{*}$

2. Yes

1. $\mathrm{No}^{*}$

2. Yes

1. $\mathrm{No}^{*}$

2. Yes

2. No

2. No

\section{Categorization}

0 . Survived to age 12 months

1. Died before age 12 months

1. Other*

2. M'baka, Yakoma, Baoulé, Ashanti, Kalenjin, Kikuyu, Bambara, Ovambo, European, Djerma- Songhai, Hausa/ Fulani/ Plateau Cluster, Hutu, Serer, Baganda, or Bemba (see Table 1 for countries)

1. Other or none*

2. Professional, technical, managerial, clerical, or skilled manual

1. Yes*

1. Yes*

VI. Use of Modern Maternal Health/Child Health Care

Tetanus Injection

1. No*

2. Yes

Number of Antenatal Visits

1. $<3^{*}$

2. $\geq 3$

* Reference category in the analysis 


\section{Notes}

1. Kaplan's Atlantic Monthly article, which linked the "rise of tribal domains" with "the unchecked spread of disease" (p. 48), was largely based on his observation of war in Sierra Leone in the early 1990s.

2. Countless definitions of ethnicity have been employed, and the literature on African ethnicity is notoriously contentious with respect to terminology (Davidson 1992; du Toit 1978; Young 1976). Confusion is perhaps inevitable because ethnic affiliation may be fluid and overlapping, particularly in Africa's urban settings (Cohen 1975), and class interests may override ethnic solidarity as modernization proceeds. In general, however, in most of Africa "solidarity across ethnic lines is weak" (French 1998:3). The ethnic groups discussed in this study can be considered to meet the following criteria: they speak a single language or dialect; have a single social organization; share a common religion; have a sense of identity, cohesion, and history; and have a single set of customs and behavioral rules (as in marriage, clothing, diet, taboos, and so on) (Middleton and Rasaam 1995). We use static descriptions of ethnicity, as identified by survey respondents, and use the terms ethnicity and ethnic affiliation interchangeably.

3. In patrilineal societies, children may be more likely to assume their fathers' ethnic identity. However, data do not exist with which to examine child health and mortality according to fathers' ethnicity in Africa. Child health outcomes have been studied in communities where men's ethnicity is known — for instance, in Bledsoe's (1990) work among the Mende in Sierra Leone-but these ethnic communities have been studied in isolation. 
4. Similar results, based on World Fertility Survey data, are presented for Kenya by Ewbank, Henin, and Kekovole (1986) and for Senegal by Cantrelle et al. (1986).

5. The variable used in the Nigeria DHS to identify local language of the respondent is "snlangr," and the 92 categories identified are classified to correspond with the ethnic groupings used by Morrison, Mitchell, and Paden (1989). In some countries where surveys were conducted during 1990-95-for instance Cameroon, Madagascar, and Malawiidentification of ethnicity was deemed too politically sensitive or potentially too unreliable for inclusion in the questionnaire. We do not use the 1994 Zimbabwe survey because the Zezuru Shona, of which Prime Minister Mugabe is a member, are not distinguished from the Shona as a whole. The 1992 Tanzania survey is not used because the ethnic groups of Presidents Nyerere and Mwinyi each comprise less than 5 percent of the national population, precluding reliable estimation of child mortality for these groups.

6. The descriptive analysis uses additional individual, household, and community-level variables that are self-explanatory.

7. For Côte d'Ivoire, we exclude the immigrant population since their representativeness in 1995 of all immigrants at any time during 198595 is unknown, and because most other surveys did not identify immigrants. The Ashanti in Ghana are coded as 1 and 2 in variable 131 of the Ghana DHS, and do not represent the Akan-speaking population as a whole. The European population in Namibia is comprised of Germans, Afrikaaners, and English. 
8. The bottom row of Table 6 presents the odds ratio of infant mortality of ethnic group members after controlling for all independent variables considered in the models and listed in Appendix A.

9. The Hausman test is only plausible if $\beta_{2}>\beta_{1}$.

10. In Figure 2, estimates for the two earliest five-year periods (e.g., 196872 and 1973-77 in Kenya) are derived from World Fertility Survey (WFS) data, while estimates for the three most recent periods are calculated from Demographic and Health Survey (DHS) data. It is necessary to use WFS data for the earlier periods because of the likelihood of differential underreporting of child deaths among ethnic groups in the more distant past as recorded in the DHS.

11. Since ethnic affiliation has been neglected in most previous analyses of child mortality based on data sets such as the DHS and WFS, consideration of ethnicity may substantially alter the well-documented strong, positive effects of maternal education, urban residence, use of modern health services, and other factors on child survival in Africa. That is, pronounced effects of these variables on child survival may be capturing in part the effects of ethnic affiliation.

12. This may reflect either (or both) superior availability of electricity and high status occupations for these ethnic groups, or stronger effects of these features on infant mortality among these groups than among others, since regression estimates are based on both exposure to conditions and effects of conditions.

13. The under-five mortality rate (5q0) during $1989-93$ was 36.1 for the Kikuyu and 125.1 for the non-Kikuyu in Kenya. In comparison, even 
West African countries such as Cameroon, Côte d'Ivoire, and Senegal had average child mortality rates below 125 in 1994 (UNICEF 1996).

\section{References}

Bledsoe, Caroline. 1990. "Differential care of children of previous unions within Mende households in Sierra Leone," in John Caldwell et al. (eds.), What We Know about Health Transition: The Cultural, Social, and Behavioural Determinants of Health: The Proceedings of an International Workshop, Canberra, May 1989, Vol. II, pp. 561-583. Canberra: Health Transition Centre, Australian National University.

Brass, William and Carole L. Jolly (eds.). 1993. Population Dynamics of Kenya. Washington, DC: National Academy Press.

Caldwell, John C. 1976. The Socio-Economic Explanation of High Fertility. Canberra: Australian National University.

Callaghy, Thomas M. 1984. The State-Society Struggle: Zaire in Comparative Perspective. New York: Columbia University Press.

Campbell, Aidan. 1997. Western Primitivism: African Ethnicity. A Study in Cultural Relations. London: Cassell.

Cantrelle, Pierre and P. Livenais. 1980. "Fécondité, allaitement, et mortalité infantile: Différences inter-ethniques dans une même région: Saloum (Sénégal)," Population 3: 623-648.

Cantrelle, Pierre et al. 1986. "The profile of mortality and its determinants in Senegal, 1960-1980," in United Nations, Determinants of Mortality Change and Differentials in Developing Countries: The Five-Country Case Study Project. Population Studies No. 94, pp. 86-116. New York: United Nations.

Clark, Sam et al. 1995. "Ten thousand Tonga: A longitudinal anthropologi- 
cal study from southern Zambia, 1956-1991," Population Studies 49, no. 1: 91-110.

Cohen, Abner (ed.). 1975. Urban Ethnicity. London: Tavistock Publications.

Conteh-Morgan, Earl. 1997. Democratization in Africa: The Theory and Dynamics of Political Transitions. Westport, CT: Praeger.

Davidson, Basil. 1992. The Black Man's Burden: Africa and the Curse of the Nation-State. New York: Times Books.

du Toit, Brian M. (ed.). 1978. Ethnicity in Modern Africa. Boulder, CO: Westview Press.

Ewbank, Douglas, Roushdi Henin, and John Kekovole. 1986. "An integration of demographic and epidemiologic research on mortality in Kenya," in United Nations, Determinants of Mortality Change and Differentials in Developing Countries: The Five-Country Case Study Project. Population Studies No. 94, pp. 33-85. New York: United Nations.

French, Howard W. 1998. "In Africa's harsh climate, fruits of democracy," New York Times, 4 January, Section 4, p. 3.

Gaisie, Kwesi, Anne R. Cross, and Geoffrey Nsemukila. 1993. Zambia Demographic and Health Survey, 1992. Columbia, MD: University of Zambia, Central Statistical Office of Zambia, and Macro International.

Gaisie, Sam. 1990. "Culture and health in sub-Saharan Africa," in John Caldwell et al. (eds.), What We Know about Health Transition: The Cultural, Social, and Behavioural Determinants of Health: The Proceedings of an International Workshop, Canberra, May 1989, Vol. II, pp. 609-627. Canberra: Health Transition Centre, Australian National University.

Gould, William T. S. 1988. "Urban-rural migration in Western Province, Kenya," in International Union for the Scientific Study of Population, African Population Conference: Dakar, Senegal, November 7-12, 1988, Vol. 2, Section 4.1, pp. 41-55. 
Griffiths, Ieuan Ll. 1993. The Atlas of African Affairs, 2nd edition. New York: Routledge.

Gugler, Josef (ed.). 1996. The Urban Transformation of the Developing World. Oxford: Oxford University Press.

Harden, Blaine. 1990. Africa: Dispatches from a Fragile Continent. New York: W. W. Norton.

Hausman, Jerry A. 1978. "Specification tests in econometrics," Econometrica, 46: 1251-1271.

Hill, Allan G. (ed.). 1985. Population, Health, and Nutrition in the Sahel: Issues in the Welfare of Selected West African Communities. London: KPI.

Hill, Allan G. and Sara Randall. 1984. "Différences géographiques et sociales dans la mortalité infantile et juvénile au Mali," Population 39, no. 6: 921-946.

Jackson, Robert H. and Carl G. Rosberg. 1982. Personal Rule in Black Africa: Prince, Autocrat, Prophet, Tyrant. Berkeley: University of California Press.

Kaplan, Robert D. 1994. "The coming anarchy," The Atlantic Monthly 274, no. 2:44-76.

Kasfir, Nelson. 1976. The Shrinking Political Arena: Participation and Ethnicity in African Politics. Berkeley and Los Angeles: University of California Press.

Kitching, Gavin. 1980. Class and Economic Change in Kenya: The Making of an African Petite Bourgeoisie, 1905-1970. New Haven: Yale University Press.

Krieger, Joel (ed.). 1993. The Oxford Companion to Politics of the World. New York: Oxford University Press. 
Kuate Defo, Barthélemy. 1992. "Mortality and attrition processes in longitudinal studies in Africa: An appraisal of the Iford surveys," Population Studies 46, no. 2: 327-348.

LeVine, Robert A. et al. 1994. Child Care and Culture: Lessons from Africa. Cambridge, UK: Cambridge University Press.

Londregan, John, Henry Bienen, and Nicolas van de Walle. 1995. "Ethnicity and leadership succession in Africa," International Studies Quarterly 39, no. 1: 1-25.

Mazrui, Ali A. 1978. "Ethnic tensions and political stratification in Uganda," in du Toit 1978: 47-68.

Mensch, Barbara, Harold Lentzner, and Samuel Preston. 1985. Socio-Economic Differentials in Child Mortality in Developing Countries. New York: United Nations.

Metz, Helen C. (ed.). 1992. Nigeria: A Country Study. Washington, DC: Library of Congress.

Middleton, John and Amaal Rasaam (eds.). 1995. Encyclopedia of World Cultures, Volume IX: Africa and the Middle East. Boston: G. K. Hall and Co.

Morrison, Donald G., Robert C. Mitchell, and John N. Paden. 1989. Black Africa: A Comparative Handbook, 2nd edition. New York: Paragon House and Irvington Publishers.

Mosley, W. H. 1983. "Biological contamination of the environment by man," in Samuel H. Preston (ed.), Biological and Social Aspects of Mortality and the Length of Life. Liège, Belgium: Ordina Editions.

Moss, Joyce and George Wilson. 1991. Peoples of the World: African South of the Sahara, First Edition. Detroit: Gale Research.

National Council for Population and Development (NCPD), Central Bureau of Statistics (CBS), and Macro International. 1994. Kenya Demographic 
and Health Survey, 1993. Calverton, MD: NCPD, CBS, and Macro International.

Newbury, Catherine. 1988. The Cohesion of Oppression: Clientship and Ethnicity in Rwanda, 1860-1960. New York: Columbia University Press.

Pison, Gilles et al. 1995. Population Dynamics of Senegal. Washington, DC: National Academy Press.

Prunier, Gérard. 1995. The Rwanda Crisis: History of a Genocide. New York: Columbia University Press.

Sen, Amartya. 1993. "The economics of life and death," Scientific American 268, no.5: 40-47.

Sombo, N'Cho et al. 1995. Enquête Démographique et de Santé, Côte d'Ivoire, 1994. Calverton, MD: Institut National de la Statistique du Côte d'Ivoire and Macro International.

Tabutin, Dominique and Eliwo Akoto. 1992. "Socio-economic and cultural differentials in the mortality of sub-Saharan Africa," in Étienne van de Walle, Gilles Pison, and Mpembele Sala-Diakanda (eds.), Mortality and Society in Sub-Saharan Africa, pp. 32-64. Oxford, UK: Clarendon Press.

Umoren, Joseph A. 1995. Democracy and Ethnic Diversion in Nigeria. Lanham, MD: University Press of America.

Ungar, Sanford J. 1986. Africa: The Peoples and Politics of an Emerging Continent. Revised and updated edition. New York: Simon \& Schuster.

United Nations Children's Fund (UNICEF). 1996. The State of the World's Children 1996. New York: Oxford University Press.

- 1997. The State of the World's Children 1997. New York: Oxford University Press. 
van Ginneken, Jeroen K. 1990. "Behavioural factors affecting transmission and treatment of acute respiratory infections," in John Caldwell et al. (eds.), What We Know about Health Transition: The Cultural, Social, and Behavioural Determinants of Health: The Proceedings of an International Workshop, Canberra, May 1989, Vol. II, pp. 843-865. Canberra: Health Transition Centre, Australian National University.

Young, Crawford. 1976. The Politics of Cultural Pluralism. Madison, WI: University of Wisconsin Press. 


\title{
POLICY RESEARCH DIVISION WORKING PAPERS
}

\author{
Recent Back Issues
}

1996

*83 Sajeda Amin, Ian Diamond, and Fiona Steele, "Contraception and religious practice in Bangladesh."

84 John B. Casterline, Aurora E. Perez, and Ann E. Biddlecom, "Factors underlying unmet need for family planning in the Philippines."

85 Geoffrey McNicoll, "Governance of fertility transition: Regularity and duress."

*86 John Bongaarts, "Population pressure and the food supply system in the developing world."

87 Sajeda Amin, "Family structure and change in rural Bangladesh."

*88 John Bongaarts and Susan Cotts Watkins, "Social interactions and contemporary fertility transitions."
*89 Cynthia B. Lloyd and Mark R. Montgomery, "The consequences of unintended fertility for investments in children: Conceptual and methodological issues."

* 90 Zeba Sathar and Sonalde Desai, "Work patterns in rural Pakistan: Intersections between gender, family, and class."

*91 Mark R. Montgomery, "Learning and lags in mortality perceptions."

92 Ann E. Biddlecom, John B. Casterline, and Aurora E. Perez, "Men's and women's views of contraception."

\footnotetext{
* No longer available
} 
93 James F. Phillips, Fred N. Binka, Martin Adjuik, Alex Nazzar, and Kubaze Frank Adazu, "The determinants of contraceptive innovation: A case-control study of family planning acceptance in a traditional African society."

94 John Bongaarts and Sajeda Amin, "Prospects for fertility decline and implications for population growth in South Asia."

95 Barbara S. Mensch and Cynthia B. Lloyd, "Gender differences in the schooling experiences of adolescents in low-income countries: The case of Kenya."

96 Martin Brockerhoff and Ellen Brennan, "The poverty of cities in the developing world."

97 Carol E. Kaufman, "Reproductive control in South Africa."

98 John Bongaarts, "Trends in unwanted childbearing in the developing world."

99 Mary Arends-Kuenning, "How do family planning workers' visits affect women's contraceptive behavior in Bangladesh?"
100 Mark R. Montgomery and Cynthia B. Lloyd, "Excess fertility, unintended births, and children's schooling."

101 Mary Arends-Kuenning, "The equity and efficiency of doorstep delivery of contraceptives in Bangladesh."

102 Sajeda Amin, Ian Diamond, Ruchira T. Naved, and Margaret Newby, "Transition to adulthood of female factory workers: Some evidence from Bangladesh."

103 Margaret E. Greene and Ann E. Biddlecom, "Absent and problematic men: Demographic accounts of male reproductive roles."

104 Michael P. Todaro, "Urbanization, unemployment, and migration in Africa: Theory and policy."

105 Geoffrey McNicoll, "Population and poverty: A review and restatement."

\section{8}

106 Sajeda Amin and Gilda Sedgh, "Incentive schemes for school attendance in rural Bangladesh."
107 Martin Brockerhoff and Paul Hewett, "Ethnicity and child mortality in subSaharan Africa." 